\title{
BURGENLAND CROATS BETWEEN VIENNA, BRATISLAVA AND SOPRON: HISTORICAL, CULTURAL AND LINGUISTIC ASPECTS $^{1}$
}

\author{
DARJA VASHCHENKO - ANNA PLOTNIKOVA \\ Institute of Slavic Studies, Russian Academy of Science \\ annaplotn@mail.ru, daranis@mail.ru
}

\begin{abstract}
The present paper discusses the written tradition of Burgenland Croats currently residing in the South of Slovakia. Before the Second World War this group of Burgenland Croats belonged to Hungary, so the preserved letters of rural residents of the border village Chunova retain a number of features characteristic of the Hungarian orthography of the beginning of last century, lexical borrowings from the languages of the environment (primarily German) and dialect features which have been lost by now. The correspondence from the beginning of the last century reflects the cultural, historical and linguistic situation typical of Burgenland Croats living in the enclave. A study of their letters published recently, in 2017, reveals the traits of their language, everyday life and some features of traditional folk culture.
\end{abstract}

Keywords: cultural and historical situation, handwritten heritage, Latin, naive spelling, Croatian, Hungarian, lexical borrowings, dialect features.

The present investigation is based on the cultural-linguistic analysis of the letters of an inhabitant of the village Chunovo, J. Stefanchich, and his numerous relatives and neighbours living in the village. The letters were written before and during the First World War (the texts refer to the period between 1908-1918). They were published in the second volume of a monograph on this village: Maász J., Mallinerits $J$. Čunovo. T. II. Sudbina Jandre Štefančića osud Ondreja Štefancsicha. Bratislava, 2017 (henceforth: Čun). ${ }^{2}$ Croatian Chunovo is currently on the border of three countries - Slovakia, Hungary and Austria, representing the South standstill within the city of Bratislava. This small Hungarian territory was not annexed to Slovakia (three villages on the right sight of Danube) until after the Second World War, which is why Hungarian is still spoken in the village of Chunovo (alongside Slovakian and Croatian). The older generation of inhabitants tend to speak Hungarian, while the middle generation uses it as a "secret" language in specific situations when they feel that there is no need for others to understand the meaning of their conversation.

Our ethno-linguistic field research in Chunovo and the nearby villages of Rusovce and Jarovce held in May 2018 allowed us to compare the Burgenland 
Croatian spoken in Chunovo today with the language that is reflected in correspondence from the early $20^{\text {th }}$ century. Geographical names in the title of the article are given as they appeared in Croatian villages at the time of our field research in Chunovo.

In the beginning of the book, authors Ive Maas and Stefan Miletich give their own opening comment (in Slovakian and Burgenland Croatian) on the nature of the correspondence. Their decision to represent in the book both photos of some (but not all) of the original letters and their translations into modern Burgenland Croatian is interesting from the point of view of the modern outlook on peculiar properties of Croatian and its spelling in the beginning of the last century. They describe the language as "partly Hungarian" (Čun: 52), and as one that was being replaced by modern Burgenland Croatian at the time when the letters were produced. It is also important to know that private informal correspondence from the territory of former Austria-Hungary has been scarcely investigated. In this case, based on the analysis of the letters, we seek to offer a general cross-section of the linguistic and ethno-cultural situation that emerges in the Croatian enclave which was located between "Beč" [Vienna], "Pozhon" [Bratislava] and Sopron at the beginning of the last century.

In terms of locations, the correspondence covers the North (Austria-Hungary) and the South (Bosnia and Herzegovina), i.e. towns where Jandre, the writer of these letters, was in service: Trebinje, Bosanski Brod, Mostar (Čun: 94, 111, 115). According to the letters, the geographical movements of Chunovo's inhabitants at that time were mostly confined to the "Pozhon, Beč, Sopron" triangle and the surrounding villages such as Rakindrof (Germ. Rakindorf, Hung. Rajka), which is now on the Hungarian side, Rosvar or Rosfar (Slovakian Rusovce) and Jandrof (Slovakian Jarovce). As regards the names of towns and villages used in letters sent from Chunovo, in addition to Vienna and Pozhon, where the relatives and friends of J. Stefanchich were working, the most frequently mentioned village is Raika (in the Croatian version Rakindrof), which is where the post-office operated and which was a regional centre for performing most administrative tasks. Besides, the letters feature not only neighbouring Rusovce (Burg.-Croat. Rosvar) and Jarovce (Burg.-Croat. Jandrof), which are now part of Slovakia as part of an areas spreading as far as Chunovo, but also surrounding villages Pandorfalu (Burg.- Croat. Pandrof) (Čun: 110) and Bijelo Selo (Čun: 74), i.e. Croatian villages in Northern Burgenland that are now in Austria; Najhof (Germ. Neuhof, that is now part of the commune Untersiebenbrunn, lower Austria) (Čun: 70), Germ. Karlhof (Čun: 70), and on the territory of modern Austria neighbouring Nimski Jandrof, Burgenland village (Veliki) Borištof appearing in letters as Borištrof (Čun: 88, 90) ${ }^{3}$ that is in the territory of modern Austria in middle Burgenland, and Kittsee (usually appearing in the Croatian version as Gijeca) (Čun: 135). ${ }^{4}$ In some cases, major towns or cities are also mentioned: Šopron (e.g. Čun: 57), Šomorjan 
(majka su bili Šomorjani s Štefacom i onde se je opio "my mother was in Shamorin with Shtefats, and there he drank" (ČUN: 62)) or Komarnov (Čun: 58). Sopron is also represented as a centre for performing acts of an administrative nature: visits to Shamorin and Komarno have a character of their own, being associated with separate, exclusive trips and experiences. The same applies to Budapest, cf. the description of the funeral which was attended by a large number of relatives and friends, including Pešta (Čun: 88).

Analysis of the orthography used in the published letters from the beginning of the $20^{\text {th }}$ century gives us the opportunity to highlight a number of traits in the writing of the Croats of this region. First of all, there is a tendency to emulate Hungarian, including the old Hungarian orthography, for example, the digraph $c z$, which was officially changed to $c$ only after 1926, so it consistently appears in words such as otacz (otac) or Maricza (Marica). We can also observe other characteristics of Hungarian spelling with regard to lexical units of Burgenland Croatian:

1. transmission of [1'] as ly: dragolyublyeni, pohvalyen (dragoljubljeni, pohvaljen);

2. transmission of [č ] as cs: csuda, csa, csemerncsas (čuda, ča, čemern čas);

3. transmission of [s] as sz: piszat, dosztat, szeda (pisat, dostat, seda);

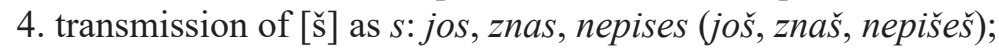

5. transmission of [ž] as zs: zselyim, zsito (želim, žito).

As an example, we provide a phrase which reflects all of these features: vasemu Kerszztnomu Patronu od szerca zselyim jos csuda let odzsiviti (vašemu Kerstnomu patronu od serca želim još čuda let odživiti) [I sincerely wish your godfather many years to live]. The sound [ć] which is absent in the Hungarian language is usually represented by the letters ch: chacha, na kipichi (ćaća, na kipići).

All these observational data are explained by the fact that the village was located within the borders of Hungary and education took place in Hungarian, as evidenced by phrases from the letters, for example, a va školu je došla lerica doklje, a to je ugrica ("and the teacher came to the school, and she is Hungarian") (Čun: 97) and other similar instances. However, literate Croatians also had the opportunity to see and read newspapers and magazines, as follows from the content of the letters (e.g. phrases like "the newspapers came today", or: pak sada čuda novine štemo, hrvatske cajdunge dojdeju "and now we read a lot of news and have Croatian newspapers coming" [Čun: 94], and so on).

The sequences employed when writing Burgenland Croatian using Hungarian orthography tend to vary somewhat among different participants of the correspondence. The most consistent system of Hungarian spelling is represented by the sister of J. Stefanchich. J. Stefanchich's father transcribed the sounds [1'],

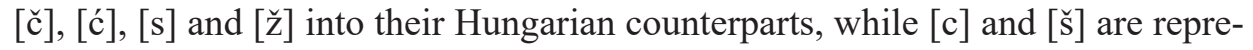
sented in their German spelling: Mariza, szerzem, otaz (Marica, sercem, otac); 
zaverschim, kaschaly (zaveršim, kašal'). It is also worth considering, in the father's letter, the stable epistolary formula of the time: Pohvalyen Jezus Krisztusch (Pohvaljen Jezuš Kristuš). Here [1'] is represented by ly in accordance with Hungarian rules, while the second sh is used not with the Hungarian, but the German spelling. In the mother's writing, in turn, there is a partial departure from the Hungarian norms of the time and a proximity to the phonetic principle of writing. Just how low the mother's standard of education must have been is evidenced by the phrase: Meni hojt to pisanje ne gre tako friško «now I can't do this writing so easily» (Čun: 88); ja sam tako, da biš mjesto mene ti jim pisao, kad ja tako ne znam «The way I am, it would be better if instead of me, you were to write to them, since I don't know how to go about it» (Čun: 88), i. e. she requests her son to write to the relatives in Vienna; kad mi se Marica smije da tako mrazno pišem «because Maritza laughs at me that I write so badly» (Čun: 92). In the mother's letters we can see: Dragoljubno dite (where [ $\left.l^{\prime}\right]$ is transmitted as $l j$, and not as ly); naszinakosi (na sinakosi), where the first [s] is written with the Hungarian spelling as $s z$, but second is transmitted as $s$ (as it sounds). The preposition $v a$ the mother spells as $w a$, i. e. in German transliteration. In turn, the son (J. Stefanchich) with the advancement of his army service in Bosnia shows a gradual departure from the Hungarian spelling and a transition to Serbo-Croatian, as we can already see in a letter from the end of 1912: vojsko, deržat, jasam, šopron (and not vojszko, derzsat, jaszam, Sopron, as before). In his last letters, the Hungarian rule is actually only a part of the sustainable formulas and applications (for example, Preljubljeni Szztarjii, mila szeszticza, where [1'] is written with the Croatian spelling, but [s] and [c] are spelt in Hungarian).

Hungarian orthography is used, regardless of the specific idio-style of the author, when writing the names of localities remote from Chunovo: $u$ Nyiregyhazi «in Nyiregyhaza» (Čun: 199); Ja sam se vozio Nagy Kanizsa «I went to Nagykanizsa» (Čun: 110); in last case it is characteristic that the Hungarian locative is used without a preposition (see also constructions without prepositions in the Croatian context: bili Požoni «were in Pozhon» (Čun: 98); bili Rosvari «were in Rusovce» (Čun: 90)). In some cases, when naming particular places preference is given to the Croatian option: Szegedin (Hung. Szeged), where Hungarian graphics are superimposed on the Croatian version of the name (Čun: 199). Pozhon (Bratislava) is most often written in the Croatian version Požon, however, in some places the Hungarian spelling is used: Pozsony (Čun: 164).

Addresses in the letters and postcards are usually given in German, regardless of the specific city (thus, the German spelling is equally characteristic of addresses in Vienna and Pozhon). In the first of the following examples the address is written in German, and the name of the city is in its Hungarian form, with the Hungarian spelling: Adres Filip Gregoric N48 Slosstrasn Pozsony, Familie Gregorich (Čun: 164); in the second example, the address is again written entirely in 
German, and the name of the city in the Hungarian form, but with the Croatian spelling: Hercecog Fridrihstrasse 24 ba in Herrn Kristlbaua Pozonj (Čun: 62); in the third example, the address is written in German with a single Hungarian impregnation (sz) for [s], and the name of the city, respectively, in the Hungarian version with Croatian spelling: pozdravljamo vse skupa Cunovce a sada bivamo $n a$ («Greetings from all of us, residents of Chunovo; now we are living at...») Slostrasse 58 2st ti 5 M.S. goszthaus Mokplocz No 19. In Požonj (Čun: 61). Similarly frequent are instances where the address and name of the addressee are spelt entirely in German: Andreas Gregorich. Hainburggasse H. Nr. 14 in Pressburg (Čun, 75).

It is characteristic that the Hungarian influence in the letters is manifested mainly in the structure: lexical borrowings from the Hungarian language are not so numerous despite the fact that the texts of the letters are, in general, quite saturated with foreign language vocabulary. Thus, the names of the months are used in their Hungarian version: 5. Augustuša «fifth of August» (Čun: 75); ta lipi augustuš «this beautiful August» (Čun: 117). In addition, lexemes of a Hungarian origin are used to refer to units of state/administrative division: $i z$ šopronske varmeje (< Hung. vármegye 'district') (Čun: 78), also orsag (< Hung. ország 'country') in one of J. Stefanchich's letters from Trebinj (Herzegovina) (Čun: 156). In a different case, the Hungarian word appears when the nomination is duplicated, when the same piece of reality is first referred to in German, and then in Hungarian: in the story of the furniture factory: Möbelfabrika, Bútorgyár (Čun: 98). In a series of letters when connecting their authors with Jandre Stefanchich, the latter's name is represented in its Hungarian version: dragi Andras «dear Andras» (Čun: 130), see also the usage tovaruš András «friend Andrash» (Čun: 98), where the common name is given in the Croatian spelling, while the proper name is used in the Hungarian. Similarly, the name is again used when saying goodbye to the addressee: Serbus Andraš zbogom «Bye, Andrash» (Čun: 112), where the Hungarian version of the name is used but with the Croatian spelling, i.e. with diacritics in the designation of sizzling sounds.

The style of letters, full of fanciful and even courtly formulas toward each other (Pohvalyen budi Jezus Krisztus, dragolyublyeni kum; Dragolyubno dite, zi mirnim szerzem zimlyem pero va ruke; Dragoljubno dite, wa jime Bozsje szam zela pero va desnu ruku), allows us to form an idea of the style of written communication used among Croats in Austria-Hungary in the beginning of the last century. Formulas of politeness quite often include lexemes of the category of people's condition that are calques from German: hofendlih, hofenlih $(<$ hoffentlich - hopefully): hofendlih ostat "remain in hope" (Čun: 177); kudi noht (< Gute nacht - good night); (Čun: 81, 84); serbus (Čun: 205); Lebe wohl auv ain Widrsehen "farewell, goodbye" (Čun: 131); Lebet wohl auf und gut "goodbye, all the best" (Čun: 277); Frainčoft, frainšoft (< Freundschaft - friendship): pozdravljam 
vas frainčoft "I welcome you in a friendly way" (Čun: 73); Lebevohl: juni šlus lebevohl Mostar und anfangs august militer gremo na urlaub "in June, goodbye Mostar and the military beginning, August, go on vacation" (Čun: 115).

Borrowings from the German language in the usage of these letters are extremely numerous, and they usually belong to certain thematic groups:

A) Words from the administrative and legal, as well as military sphere: ongelegenheit (business): vaš ongelegenheit povidat «it is your business to tell» (Čun: 155); ima ongelegenheit zaistinu «he has his business» (Čun: 155); vse vaše ongelegenheite (Čun: 269) «all of your business works»; onvajzung ( $<$ Anweisung - instruction): na onvajzungi «under the instruction» (Čun: 108); donesla onvajzungu «has brought instructions» (Čun: 142); nimate onveizungu «you have no instructions» (Čun: 158); versendung (parcel): sam dostao versendungu «I received the parcel» (Čun: 207); urlaub (vacation): na urlaub dojt «go on vacation» (Čun: 59); dni urlauba «vacation's days» (Čun: 66); gremo na urlaub «we go on vacation» (Čun: 115); tako je sada opet s našim urlaubom «so is now again with our vacation» (Čun: 154); nisu dali urlauba «not given a vacation» (Čun: 168); unteršit (< Unterschrift - signature): nimamo unteršita «we have no signature» (Čun: 250); auskunft, auskunst (< Auskunft - information): kakov auskunft «any information» (Čun: 124); daj mi sada auskunst «give me some information now» (Čun: 99); ausceihnung (< Auszeihnung - reward): moj šicen ausceihnung «my reward» (Čun: 157); ceignis (< Zeugnis - witness): a s tim ceignisom nujte pojt štujrihteru «and with this witness you need to go to the mayor» (Čun: 155); gesuh (request, petition): štujrihter neka pošalje gesuh direkt «let the mayor send a request directly» (Čun: 155); tr da gesuh pošalje «let him send you a request» (Čun: 164); hauptmon (< Hauptmann - captain): od hauptmona «from the captain» (Čun: 62);

B) Words from the family and festive sphere: Gepurctag ( $<$ Geburtstag - birthday): na 3. je moj gepurctag «the third is my birthday» (Čn: 206); $k$ geburstagu «to the birthday» (Čun: 239); Namenstag (name-day): moj 30. ljetni Namenstag «my name-day in thirty years» (Čun: 234);

C) Designations of some household items: ceidung, cejdung, caidung $(<$ Zeitung - newspaper): a za tu zvijezdu smo štali va cejdungi «and about this star we have read in the newspaper» (Čun: 90); cug (< Zug 'train'): dojdeš na prvi cug «take the first train» (Čun: 131); cug je dostao «the train has arrived» (Čun: 151);

D) Names of some mental actions and states: the verb pelaidigati se, peleidigati se (< Beleidigen - offend): more pri tebi jako merkat, da se s tim ne pelaidigaš «he should be watching you well, don't be offended by that» (Čun: 205); ali oni su si zaslužili, ali neka se ne pelaidigaju «but they deserve it, and don't be offended» (Čun: 272); also hofati, hofnung (hope): sam doslje hvala Bogu zdrav, ča i od vas hofam «Until then, I am well, thank God, and hope that you are also» (Čun: 180); naša vojska i imaju hofnungu i Lemberg vreda najzad dostat «it is hoped 
that our troops will beat Lemberg back» (Čun: 184); smo va velikoj hofnungi na blaženi mir «we really hope for (we are in great hope of) a prosperous peace» (Čun: 225);

E) A separate group is formed by borrowings united by a common structural format - first of all we are talking about German prefixed verbs and verbal nouns. Among the borrowings are derivatives with German verb stems, for example: auskenat (< Auskennen 'know about') ništ ni, se ne auskenam «there is nothing, I don't know of anything» (Čun: 260); ausšteljati (<Ausstellen 'expose'): to vam moraju ausšteljat «you have to put this» (Čun: 155); ausseng (outlook, perspective $<$ Aussehen - to look out or to look like): nikarkov ausseng za domom pojt «any prospect of going home» (Čun: 167); ajnperufung (< Einberufung - conscription, convocation (for the army)), čuda ajnperufungov došlo «there have been numerous summons» (Čun, 66);

Of particular significance is the lexeme Umgong, umgang, which is used in letters to refer to Church processions and ritual marches that were conducted in the village on certain holidays, see: umgong crikvi «the procession around the Church» (Čun: 123); umgong na Tjelovu «the procession on Corpus Christi» (Čun: 124);

Extremely frequent is the use of the borrowed modal verb prauhat $(<$ Brauchen 'to need, to be necessary'): Prauhali platiti «they needed to pay», skrbi ne prauhaš imat «you shouldn't feel grief», za Maricu ne prauhaš bojat «you shouldn't be afraid for Maritza» (Čun: 77); neprauhate toliko skrbit «you don't need to worry so much» (Čun: 79) It is also possible to use isolated individual prefixes borrowed from German, which in this case appear as the words describing various categorical states: jutro u 4 ura sam auf «I'm free at four in the morning» (Čun: 64); to baba su još tako daleko zdravi i teta su takaj auf «grandma is also quite healthy and aunt is also good» (Čun: 84); a zutra to je pandiljak sam dao auf «and tomorrow, on Monday morning I was free» (Čun: 86).

Actively borrowed words of categorical states, adverbs, and adjectives also belong here. We frequently come across the use of fertik, fertig (ready): sada smo fertik «today we are ready» (Čun: 129); subotu sme bili fertik «on Saturday we were ready» (Čun: 129), also fleisik, fleisig (diligently), hojt (< heute 'today') pri nas hojt fleisig prši «we have heavy rain today» (Čun: 283); naši mi fleisik pišu «we often write to me» (Čun: 211); forleifig (< vorlaufig - temporarily): sam simo došao i ćemo forleifig ovde ostat «I got here, and we temporarily want to stay here» (Čun: 179); drugačije novine forleifig ni «no other news yet» (Čun: 264); genslih (gänzlich - absolutely, totally): ako me genslih ne moru pušćat «if I absolutely can't let go» (Čun: 164); lustig, lustik (funny, fun): je bilo tako lustik «it was such fun» (Čun: 81); fist lustik «very funny» (Čun: 81); tako lustig i zdrava "so funny and healthy» (Čun: 262), feš (<fesch - perky, cheerful), frajlih, frajdlich (< freundlich - cute, friendly): oni su jako feš človik, jako frajdlih «he's a 
very cheerful man, very sweet» (Čun: 79). All these occasional borrowings do not exist in the modern vocabulary of the Burgenland language. ${ }^{5}$

In this case, the letters we have studied reflect the predominant presence of Germanisms in the everyday speech of the beginning of the last century in comparison with Hungarian. That is due, firstly, to the perception by Croats of German as the more prestigious language of the environment (cf. the current situation, when Slovakian borrowings are predominant), and secondly, to the close contacts with the German population living not only in the neighbouring German and German-Croatian villages in Austria and in Vienna (Be $\breve{c}$ ), but also among Croats in the villages of Jarovce, Rusovce, Chunovo, as evidenced by interviews conducted during fieldwork in the present age or by inscriptions on the gravestones with German names, etc.

Clearly, the use of Hungarian spelling is predominant in the letters under consideration. This also applies to proper names: the names of towns/villages and addresses are more often spelt in the Hungarian fashion. The situation is different with regard to the everyday vocabulary of the letters: the Croatian idiom which is used in them is full of borrowings, the vast majority of which refers to German. German borrowings, in turn, reveal two main trends: 1) words borrowed from the administrative and legal sphere / from the sphere of emotions and interpersonal relations; 2) borrowings of words with a certain structural format. In addition, the text of the letters contains recurring German clichés and formulas of politeness. Such a picture seems to reflect the linguistic situation prevailing at the time in Chunovo, when the official language of instruction at the school was Hungarian, while in the sphere of oral communication with representatives of other ethnic groups the German language prevailed. In this regard, stylistic differences that are correlated with the opposition of "own - foreign" are also of interest, for example: kvartir (from Germ.) - a room, a place of residence (in the city, in another country, in the army service of the son), while the Slavism hiža (Čun: 79) is mentioned only as the father's house, "own place" in the village. The language variant preserved in letters is of particular value in view of the fact that later on Chunovo was to change its administrative affiliation repeatedly, and today the occurrence of German words in the Croatian language used by Chunovo's inhabitants is fairly limited.

The orthography of certain words also allows us to demonstrate those dialectal features in the speech of Croats in former Austria-Hungary which are currently lost in that dialect, but are preserved, for example, in the speech of Croats in Hungary, as the authors of the article had the opportunity to see during the field research of Croats in Hungary in 2017. Thus, in the Croatian village of Zhidan (Western Hungary) we observed spellings such as kerst for 'krst' meaning "cross"; serce for 'srce' meaning "heart"; kerv for 'krv' meaning "blood" and others, in the group *TRЪT, *TЪRT, which is a dialectal feature lost in con- 
temporary Chunovo (apparently, due to the re-assertion of the norm whereby the Burgenland Croatian language is seen as a modern literary micro-language). ${ }^{6}$ Such evidence can only be established from the original letters themselves, as publishers tend to unify primarily the phonetic features of texts, while leaving grammatical, syntactic and stylistic traits intact in order to convey "how it was written in the past". According to our observations, however, this procedure is carried out very inconsistently, with publishers defining that the purpose of the book is firstly to show how ordinary people lived in the village before and during the First World War, and only secondly to demonstrate the "language used by our Croats" (Čun: 52).

As is apparent by now, the language of the letters is some kind of heavily Germanized Croatian mainly transmitted with a Hungarian spelling, however, it is important to emphasize that the Croatian vocabulary of traditional spiritual folk culture is also preserved in full in the correspondence of the beginning of the last century. This fact testifies to the preservation of the folklore and ethnographic tradition in the Croatian enclave of Austria-Hungary: it is not surprising that during the field survey of the village we were able to record the terminological vocabulary of folk culture, together with the corresponding customs, rituals and beliefs, in some cases even revealing archaic elements of the Slavic tradition.

Designations of ritual realities, ritual actions and names of celebrations used in the correspondence coincide with the terminological range of traditional folk culture that was recorded during the ethno-linguistic expedition in 2018, for example:

1) within the scope of the folk calendar: badnjak 'Christmas eve' (Čun: 116), Božić 'Christmas' (Čun: 116), mesopust 'carnival' (Čun: 88, 91, 92, 98, 112), Macicna nedilja 'palm Sunday' (Čun: 97), Vazam 'Easter' (Čun: 88, 95, 112), Duhi 'Trinity' (Čun: 101), Vse svete 'all saints day' (Čun: 95), kiritof 'village feast' (Čun: 80-81, 99);

2) within the sphere of wedding rituals: pir 'wedding' (Čun: 77, 88, 90), zaručnjak 'groom' (Čun: 74), staćilo 'leader of the wedding' (Čun: 100);

3) within the sphere of funeral rites: pogreb 'funeral' (Čun: 74, 88, 115), cimiter/cimitor 'cemetery' (Čun: 83,88 ) etc.

In this layer of vocabulary no change is detected, which once again demonstrates the conservation of such terminology and corresponding archaic elements in the extra-linguistic content. Naturally, the contexts of the use of, for example, terminological units from the sphere of the folk calendar are primarily associated with the designation of time periods of rural life (for example: "before" Christmas/Easter/Trinity and "after" Christmas/Easter/Trinity, or: "he came before Trinity" (Čun: 100) and so on). At the same time, there are important details revealed concerning the folklore and ethnographic plane in particular: the enumeration of all wedding feasts in the village in the period of carnival (Čun: 112) which 
indicates the traditional time of weddings in Chunovo; or we may note the ritual arrival of the boy "to the mother's brother" at Easter: na crljeno jaje "for the red egg" (Čun: 97), indicating the traditional rounds that children would make at Easter, collecting coloured eggs; the detailed description of the village feast kiritof by the mother (Čun: 80-81), revealing both features of the celebration, and a picture of local life (especially the range of locations and surrounding areas from which people gathered in Chunovo helps reproduce the one-time geography of communication between inhabitants of Chunovo and the residents of neighbouring villages). ${ }^{7}$

Another feature of interest are records of prayers from the last century, showing generic peculiarities of the prayer-charms of Croats in Austria-Hungary at the beginning of the last century (cf. note by S. M. Tolstoy, stating that "in the tradition of the Slav Catholics the function of the spell (charm) largely took over that of prayers") $)^{8}$ and the specifics of Burgenland Croatian vocabulary in written sacred text: ${ }^{9}$

Duša Kristuševa posvetime. Telo Kristuševo zveličime. Kerv Kristuševa napojime. Voda ziz tela Kristuševoga cureća operime. O dobri Jezuše posluhnime. Od tebe razlučit nekame, od zloga Duha odbranime, va mojoj skradnjoj uri pozovime, onde ksebi primime. Stvojimi blaženi u nebeskom raju pridružime. A.m.e.n. «Soul of Christ, sanctify me. The body of Christ, glorify me. Blood of Christ, water me. The water flowing from the body of Christ, wash me. Oh, good Christ, listen to me. Let me not be separated from you. Protect me from the evil spirit. In my last hour, call me, and then receive me. To your blessed in heavenly Paradise, join me. Amen» (Čun: 159-160).

\section{Notes}

1 The author's work was carried out in the framework of project № 17-18-01373 of the Russian Scientific Foundation, «Slavic archaic zones in Europe: ethnolinguistic research».

2 Maász J., Mallinerits J. Čunovo. T. II. Sudbina Jandre Štefančića osud Ondreja Štefancsicha [Chunovo. V. II. Life Story of Jandre Shnefanchicha or Ondreja Shtefanchicha] (Bratislava, 2017).

3 By analogy with the Burgenland-Croatian forms of village names: Pandrof, Jandrof and so on.

4 Kittsee is also a part of the network of Croatian towns and villages in Northern Burgenland which are discussed in the study of the academician Gerhard Neweklovsky, see: Neweklowsky G. "Die kroatischen Dialekte des Burgenlandes und der angrenzenden Gebiete" In: Schriften der Balkankommission, Linguistische Abteilung; 25. (Wien 1978) P. 347.

5 See: Gradišćanskohrvatsko-hrvatsko-nimški rječnik. [Burgenland Croatian-Croatian-German Dictionary] (Zagreb - Eizenshtadt, 1991).

6 See in: Plotnikova A.A. Slavjanskije ostrovnyje arealy: arhaika i innovacii [Slavic Island Areas: Archaism and Innovation] (Moscow 2016.) P. 114-122.

7 Such information of folklore-ethnographic character should be considered very rare in this context due to the fact that the recipient (son, serving in the army) is familiar in detail with the 
traditional way of life in the village Cunovo, so information of domestic, logistical, economic and legal nature tends to prevail in the letters.

8 Tolstaya S.M. "Zagovory" [Charms] In: Slavjanskie drevnosti: Etnolingvisticheskii slovar. V. 2. Moskva, 1999. P. 239-244, P. 239

9 This text (molitva) had been written by Jandre Stefanchich in Trebinje in 1913, and most likely he was keeping this sheet with text as a talisman against a bullet during the First World War. A photo of the original text is provided in the book, so in this case it is possible to include it here in the original spelling. 
